Doi: https://doi.org/10.31578/jebs.v6i2.243

\title{
Diversity Management and Cultural Competency of Teacher Candidates in Blacksea Region of Turkey
}

\author{
Tuba Aydın Güngör* \\ Çiğdem Çakır**
}

\begin{abstract}
Ever since the world has been dealing with the problem called Covid-19, everything around us has had to change. This epidemic has affected our lives in many ways and has set us completely new roles and tasks on many things, and education which is one of the most important things among them had be changed. Indeed, the transformation of education had already begun with the improvement of transportation and telecommunication conditions and being able to receive education online in different countries or via the internet has brought new concepts to the academic world. Cultural competence, one of them, is shaped by identity and traditions, thus cultural diversity is the main factor in determining the characteristics of this concept. Meanwhile, the ones who realize the acculturation of the society, the people who created this concept, are the teachers who direct the society in both academic and cultural dimensions. As a result, teachers need to learn to manage diversity to be able to cope with the differences in their classrooms, as they encounter many different cultural characteristics. For this reason, in this study, it is considered worth investigating what kind of dimensions pre-service teachers can have regarding the management of diversity and cultural competencies. The population of the research consists of 1073 teacher candidates studying in Artvin Coruh University. The aim of this research was to reveal the diversity management skills and cultural competence levels of education faculty students. In order to reach more in-depth information on what management of diversity and cultural competences is, the study started with a literature review. Then, Diversity Management Scale (DMS) and Cultural Competence Scale (CCS) were applied to Artvin Çoruh University, in the Black Sea region of Turkey, to faculty of education students (teacher candidates). After the regression analysis of the data for management of diversity scale, two dimensions have been found which are managerial practices and managerial approaches. Moreover, for the cultural competencies scale three dimensions were found which are cultural knowledge, cultural sensitivity, and cultural skills. Lastly, a significant relationship was found between Diversity Management and Cultural Competence of the teacher candidates, and cultural competence was found to be a meaningful predictor of diversity management of teacher candidates.
\end{abstract}

Key words: diversity, culture, cultural competence, diversity management, teachers

\section{Introduction}

Culture creates such a mood that can directly affect people's ability to perceive, think, communicate, learn, and use technology. Although culture is so effective in a person's life, if people do not even know the characteristics of other cultures, their social

\footnotetext{
* Dr. Education Faculty, Artvin Çoruh University, Turkey

** Dr. Ministry of Education, Gaziantep, Turkey

Corresponding Email: tuba.gngr@artvin.edu.tr
} 
behaviors and attitudes may be negatively affected during their interactions with other people. Learning about different cultural characteristics makes it easier to adapt to an unfamiliar country, to live and work with the people of that country (Eğinli, 2011). Even not only to adapt to an unfamilar country, but also to adapt to an unfamilar environment farther from your local area teachers need training programs that include cultural management skills for managing diversities.

The age we are in now has become an era that brings distances thought to be very far closer and intertwines them. Therefore, from every society and every culture individuals are in communication with each other. Meanwhile, relationships among societies are gradually increasing and parallel to this increase, mutual effective communication is becoming more and more important. As a natural consequence of this, in order to ensure the mutual communication between individuals, hence cultures, individuals with high levels of competence are needed within the scope of cultures (Altundağ, 2007). Cultural competence in different cultural groups involves having acceptable knowledge, understanding and skills to offer individuals a care in their own right (Tanrıverdi, 2017)

For prospective teachers there are many challenges in their work like orientation to newcomers, cultural differences in students and managing these cultural differences in their classes. One of the main functions of education faculties in universities is to train prospective teachers with the skills necessary to deal with such issues, so universities should contribute to the education of prospective teachers with high cultural competence skills and tackle the diversity of their skills. For this reason, this study aimed to determine the effect of cultural competence level on the diversity management perception according to the opinions of teacher candidates.

\section{Literature review}

Cultural competence is defined as attitudes, practical skills and systems knowledge in intercultural situations (Chrisman, 2007); similar attitudes and behaviors that increase work efficiency in multi-cultural environments and provide a compromise between people and institutions (U.S. Department of Health and Human Services, 2001); a set of harmonious attitudes, behaviors, and principles exhibited by individuals that enable the system to function effectively in multi-cultural environments (Cross, Bazron, Dennis \& Isaacs, 1989; Yıldırım, as cited in Mason, Benjamin \& Lewis, 1993).

Husky, Deen, and Parker (2010) stated in their study that there are some skills teachers should have as a cultural competence., in addition, Cross et al. (1989 as cited in Mason et al., 1993); American Speech-Language Hearing Association (ASLHA) (2004); Burchum (2002); Hanley (1999) pulled up these skills under the name of "Cultural Competencies" under five subheadings: 1) cultural awareness skills, 2) cultural understanding skills, 3) cultural knowledge skills, 4) cultural interaction skills and 5) cultural sensitivity skills. Cultural awareness skills cover exploring personal and cultural values, tendencies, prejudices and views; identifying the ways in which culture shapes beliefs, behaviors, and values; identifying the similarities and differences between cultures; getting to know one's own culture, including the organizational culture. Cultural understanding skills cover understanding the developmental nature of cultural competences; identifying problems and concerns that arise when values, beliefs, and behaviors differ from the dominant culture to identify the pathways in which culture affects participation in organizational programs and services. Cultural knowledge skills cover being familiar with the cultures of different masses in their own geography; using conceptual and theoretical models to understand how other people's culture differs from their own; defining and utilizing cultural information sources. Cultural interaction skills cover knowing the factors affecting the intercultural communication positively; using intercultural communication concepts and theories: effectively managing intercultural conflicts; interacting efficiently, and seeking help from cultural partners. Cultural sensitivity skills cover describing historical and sociological effects on 
specific cultural formations; recognizing the impact of privilege, inequality and oppression in everyday conditions. Again, Huskey, Deen and Parker (2010) argue that individuals with these cultural competence skills are professionals who must display three behaviors:

1) Participating in culturally different environments and programs,

2) Ensuring the integration of cultural competencies in the planning, implementation, and evaluation of programs and services,

3) Implementing strategies while communicating with individuals from different cultures in professional settings.

The issue of cultural competence, the cultural competence dimensions in which these behaviors are shown, ceased to be the subject of theoretical studies since the 1990s (Weaver, 1999), in fact, it has been the subject of systematic research. Weaver followed the process as given below.

\section{The Cultural Competence Behaviors}

\begin{tabular}{|c|c|c|}
\hline 1995 & Lenburg, Lipson, Demi, Blaney, Stern, Schultz & Knowledge, behavior, skill \\
\hline 1996 & Clinton & Awareness, sensitivity \\
\hline 1997 & McPhatter & Knowledge, values, skill \\
\hline 1999 & Weaver & Knowledge, values, skill \\
\hline 2002 & Burchum & $\begin{array}{l}\text { Awareness, knowledge, understanding, sensitivity, skill, } \\
\text { interaction }\end{array}$ \\
\hline 2002 & Campinha-Bacote & Awareness, knowledge, sensitivity, behavior \\
\hline 2003 & Rew, Becker, Cookston, Khosropour, Martinez & Awareness, sensitivity, knowledge, skills \\
\hline 2004 & ASLHA & Knowledge, skill \\
\hline 2004 & Doorenbos, Schim & Awareness, sensitivity, diversity, competence \\
\hline 2005 & Doorenbos, Schim, Benkert, Borse & Awareness, sensitivity, behavior \\
\hline 2010 & Huskey, Deen, Parker & $\begin{array}{l}\text { Awareness, understanding, knowledge, interaction, } \\
\text { sensitivity }\end{array}$ \\
\hline 2012 & Perng, Watson & Knowledge, sensitivity, skill \\
\hline
\end{tabular}

As can be understood from the above explanations and the table, cultural competence generally refers to knowing cultural diversity, one's own cultural characteristics and the characteristics, values and norms of different cultures; showing understanding to differences and showing sensitivity as effects on behavior; it involved skills such as communication, problem solving, speaking and listening. In this study, the dimensions of Perng and Watson's (2012) study, which is one of the recent studies on the subject, were taken into consideration. Perng and Watson (2012) stated that cultural competence is the learning ability of an individual in the cognitive, affective, and psychomotor domains based on the idea that it will start with acquiring knowledge and end with the acquired skills. They determined the following dimensions: 1) cultural knowledge, 2) cultural sensitivity and 3) cultural skills. Cultural knowledge is seen as the basis of cultural competence. It is important for cultural competence to know the cultural 
structure of the society, social development and organization in other regions, and to know how to obtain information about them (Perng \& Watson, 2012). Cultural sensitivity is knowing the individual's own beliefs and values first; valuing cultural diversity, and respecting the impact of culture on behavior (Perng \& Watson, 2012). Cultural skills are the reflection of knowledge and sensitivity in behavior. They include general skills and control skills (Perng \& Watson, 2012).

Problems such as global crises and natural disasters (Covid-19) have begun to deeply affect globalization and demographic changes, and in this context, the need for alternative management approaches has become a necessity today. One of the new management approaches emerging in this direction is diversity management approach. According to this approach, you should manage 'the difference' in your classroom. The difference includes gender, age, language, ethnicity, cultural background, religious belief, and covers family responsibilities. Again, the difference includes education level, life, job experience, socio-economic background - status, income, seniority, personality, and marital status the condition (Giffin \& Moorhead, 2010; Magoshi \& Chang, 2009, p. 31; Lopez, 2008, p. 75; Rijamampianina \& Carmichael, 2005, p. 110; Williams \& O'Reilly, 1998, p.82).

Management of diversity helps to plan, organize, and direct the educational process, since it supports the differences that augment some performances to a certain extent (Hubbard, 2004, p. 27). Diversity management is evaluated by many researchers as a sustainable and controllable process, and this value has differences and similarities rather than controlling differences in the process emphasizing on the necessity of giving (Thomas, 1990; Maldonado et al., 2002, p. 112).

A large and growing body of literature investigates the ways in which diversity can be used for the advantage of teaching and learning and is seen as a positive force (Lumby \& Coleman 2007). Diverse ideas, cultural values, ethnic origins and histories create a wealthy structure that perceives, respects and values differences within schools and communities. When diversity is assessed, communicated as a positive force, and managed to benefit individuals and organizations, it can help tackle challenges such as racism and stereotyping (Blackmore, 2010; Haas, 2010; Shah, 2008). In spite of possibilities for seeing the increasing diversity of ethnicity within schools as an exciting opportunity for new learning and new ways of doing things, the reality is that many leaders are overwhelmed by the attendant challenge of managing multi-ethnic differences effectively (Cardno, Handjani \& Howse, 2018).

The rapid increase in the diversity of school populations in some urban settings creates a challenge for school leaders in relation to fostering ethnic inclusion as an important aspect of leading a school with a diverse student population. Studies of ethnic inclusion in schools confirm the importance of this aspect of school management in international settings where multicultural societies and multicultural schools are becoming the norm, particularly in locations of high population density (Cardno et al., 2018).

Today, educational institutions are also facing differences (Balyer \& Gündüz, 2010, p. 27). The cultural clash among teachers and students can undermine educational processes (Ladson-Billings, 2000). Cultural clashes among teachers and students can undermine educational processes and cause feelings of mistrust among students in school settings. Demographic changes, globalization, workforce differences, individualization factors affect institutions (Leicht-Scholten, Weheliye \& Wolffram, 2009, p. 447). In this regard, managing differences is valid for universities and educational organizations like schools (Lumby $\&$ Coleman, 2007, p. 2-3). Therefore, for schools that cannot manage differences successfully some problems are inevitable ( Jabbar \& Mirza, 2017).

Considering that one of the main functions of universities should contribute to education of teacher candidates with high cultural competence skills and managing diversity skills, the suggested research model (Figure 1) was developed. Within the framework of the research model given in Figure 1, this study aimed to determine the effect of cultural competence level on the 
diversity management perception according to the opinions of teacher candidates. For this purpose, the following hypotheses have been tested.

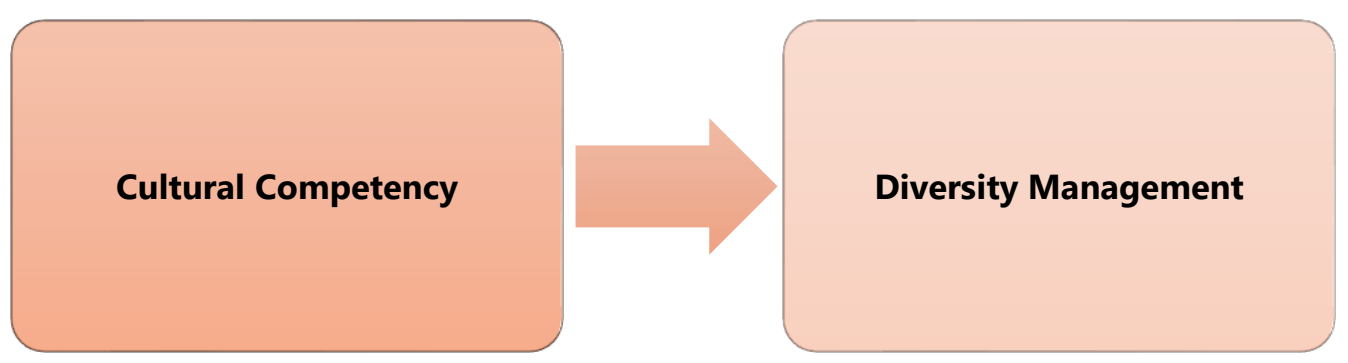

Figure 1. Research Model

$\mathbf{H}_{1}$ : There is a positive and significant relationship between cultural competence and diversity management.

$\mathbf{H}_{1 a}$ : There is a positive and significant relationship between cultural competence and managerial practices.

$\mathbf{H}_{\mathbf{1 b}}$ : There is a positive and significant relationship between cultural competence and managerial approaches.

$\mathbf{H}_{1}$ : There is a positive and significant relationship between cultural knowledge and diversity management.

$\mathbf{H}_{1 \mathrm{~d}}$ : There is a positive and significant relationship between cultural knowledge and managerial practices.

$\mathbf{H}_{1 \mathbf{e}}$ : There is a positive and significant relationship between cultural knowledge and managerial approach.

$\mathbf{H}_{1 f}$ : There is a positive and significant relationship between cultural sensitivity and diversity management.

$\mathbf{H}_{1 \mathbf{g}}$ : There is a positive and significant relationship between cultural sensitivity and managerial practices.

$\mathbf{H}_{1 \mathrm{~h}}$ : There is a positive and significant relationship between cultural sensitivity and managerial approach.

$\mathbf{H}_{1:}$ : There is a positive and significant relationship between cultural skills and diversity management.

$\mathbf{H}_{1 \mathbf{1}}$ : There is a positive and significant relationship between cultural skills and managerial practices.

$\mathbf{H}_{1 \mathbf{k}}$ : There is a positive and significant relationship between cultural skills and managerial approach.

$\mathbf{H}_{2}$ : Cultural competence is a meaningful predictor of diversity management.

\section{Methodology}

\section{Research Model}

Relational scanning model was used in the research. Relational scanning model is a scanning model that aims to determine the existence of co-change between two or more variables (Karasar, 2014). According to the opinions of the teacher candidates, the relationship between cultural competence and diversity management was determined by scales applied to teacher candidates.

\section{Research Sample}

The population of the research consists of 1073 teacher candidates studying in Artvin Coruh University, Faculty of Education in the 2019-2020 academic year. Criterion sampling, one of the purposeful sampling methods, was used in the study. The sampling 
criterion was determined as pre-service teachers who have completed their teaching internship, since only teachers with teaching experience can evaluate diversity management in their classrooms. In this context, second, third and fourth grade students were included in the sample group. While $29.7 \%$ (117) of 394 teacher candidates participating in the study were male, $70.3 \%$ (277) were female. In the sample group, $13.7 \%$ (54) were second grade, $18.8 \%$ (74) were third grade, and $67.5 \%$ (266) were fourth grade students.

\section{Data Collection Tools}

A "Personal Information Form" containing demographic variables, "Cultural Competence Scale, CCS" and "Diversity Management Scale, DMS" was used to collect data in the study. The validity and reliability studies of the scales are given below.

Cultural Competence Scale (CCS)

Its original form was developed by Perng and Watson (2012) with university students. It was translated into Turkish by Çakır and Aydın Güngör (2016) with teacher candidates. It consists of 20 items and three factors: cultural knowledge, cultural sensitivity and cultural skills. It is a five-point Likert type scale such as "strongly agree (5)", "agree (4)", "neither/nor agree (3)", "disagree (2)" and "strongly disagree (1)". Cronbach's Alpha internal consistency coefficient of the scale is 0.86 .

As a result of the analysis made in the present study, $\mathrm{KMO}$ value was found to be 0.96 . It was revealed that the value obtained as a result of Barlett's Sphericity test was significant $(X 2=7183,192, p<0.01)$. It was seen that the total variance explained was realized as $72.46 \%$. The analyses conducted have confirmed the three-factor structure. As a result of Confirmatory Factor Analysis (CFA) the fit indices of the model are Chi-squared $\left(\chi^{2}\right)=441$, degrees of freedom $(\mathrm{df})=141, p=.00 ; \chi^{2} / \mathrm{df}=3,12$; Comparative Fit Index $(\mathrm{CFI})=.96$, Adjusted Goodness of Fit Index $(\mathrm{AGFI})=.86$, Goodness of Fit Index $(\mathrm{GFI})=.90$, Normed Fit Index $(\mathrm{NFI})=.94$, Relative Fit Index $(R F I)=.92$, Standardized Root Mean Square Residual $(S R M R)=.041$, Root Mean Square Error of Approximation (RMSEA) $=.074$. According to Table 1, the model is seen to be in acceptable and good fit reference intervals (Çokluk, Şekercioğlu, \& Büyüköztürk, 2009). Cronbach's Alpha internal consistency coefficient of the scale was found to be equal to 0.97 for the overall scale, 0.90 for cultural knowledge, 0.83 for cultural sensitivity and 0.96 for cultural skill.

Table 1. Fit Indices and Reference Ranges

\begin{tabular}{lll}
\hline Fit Indices & Perfect Fit & Acceptable Fit \\
\hline$\chi 2 / d f$ & $0 \leq \chi 2 / \mathrm{df} \leq 2$ & $2 \leq \chi 2 / \mathrm{df} \leq 5$ \\
RMSEA & $0 \leq \mathrm{RMSEA} \leq 0.05$ & $0.05 \leq \mathrm{RMSEA} \leq 0.08$ \\
SRMR & $0 \leq \mathrm{SRMR} \leq 0.05$ & $0.05<\mathrm{SRMR} \leq 0.10$ \\
RFI & $0.90<\mathrm{RFI} \leq 1.00$ & $0.85 \leq \mathrm{RFI} \leq 0.90$ \\
NFI & $0.95 \leq \mathrm{NFI} \leq 1.00$ & $0.90 \leq \mathrm{NFI}<0.95$ \\
GFI & $0.95 \leq \mathrm{GFI} \leq 1.00$ & $0.90 \leq \mathrm{GFI}<0.95$ \\
AGFI & $0.90 \leq \mathrm{AGFI} \leq 1.00$ & $0.85 \leq \mathrm{AGFI}<0.90$ \\
CFI & $0.97 \leq \mathrm{CFI} \leq 1.00$ & $0.95 \leq \mathrm{CFI}<0.97$ \\
\hline
\end{tabular}


Diversity Management Scale (DMS)

The original form was developed by Ergül and Kurtulmuş (2014) with teacher cadidates. It consists of 20 items and two factors: approaches and managerial practices. It is a five-point Likert type scale such as "strongly agree (5)", "agree (4)", " neither/nor agree (3)", "disagree (2)" and "strongly disagree (1)". Cronbach's Alpha internal consistency coefficient of the scale was 0.94.

As a result of the analysis made in the present study, $\mathrm{KMO}$ value was found to be 0,97 . It was revealed that the value obtained as a result of Barlett's Sphericity test was significant $(X 2=8790,426 ; p<0.01)$. It was seen that the total variance explained was realized as \%74,758. The analyses conducted have confirmed the two-factor structure. As a result of Confirmatory Factor Analysis (CFA) the fit indices of the model are $\chi^{2}=478.390, \mathrm{df}=144, p=.50 ; \chi^{2} / \mathrm{df}=3,32 ; \mathrm{CFI}=.96, \mathrm{AGFI}=.86, \mathrm{GFI}=.90, \mathrm{NFI}=.95, \mathrm{RFI}=.93$, SRMR $=.053$, RMSEA $=.077$. According to Table 1, the model is seen to be in acceptable and good fit reference intervals (Çokluk, Şekercioğlu, \& Büyüköztürk, 2009). Cronbach's Alpha internal consistency coefficient of the scale was found to be 0.98 for the overall scale, 0.96 for managerial applications and 0.96 for approaches.

\section{Data Collection}

The study investigated and allowed by Artvin Coruh University Scientific Research and Ethical Review Board (REF: 78646441 050.01.04). The scales were sent online to teacher candidates. 455 scales were filled in, but 61 of them were deleted from the data set in the assumption analysis. As a result, 394 scales were analyzed.

\section{Data Analysis}

Within the aim of the study, the relationship between the cultural competence levels of teacher candidates and their perception levels of diversity management was examined with the Pearson correlation coefficient. Whether cultural competence is a significant predictor of diversity management was tested by hierarchical multiple regression analysis using SPSS21. The reason for performing hierarchical multiple regression analysis is to clearly reveal the effect of the main predictor variable determined by controlling the effect of other variables on the predicted variable (Can, 2017). In the present study, the effect of demographic variables on the predicted variable was controlled. LISREL 8.80 program was used for confirmatory factor analysis of the scales.

In order to decide whether the regression analysis was suitable for the data set of the research, the assumptions about the regression analysis were tested. The first of these is that the predictive and predicted variables must be continuous variables measured in at least equal interval scales and show normal distribution (Field, 2009). In order to check whether the variables show normal distribution, mean, mode, median values, and skewness and kurtosis coefficients were examined (Table 2).

Table 2. Descriptive Statistics of Predictive and Predicted Variables

\begin{tabular}{llllllll}
\hline & $\begin{array}{l}\text { Cultural } \\
\text { competence }\end{array}$ & $\begin{array}{l}\text { Cultural } \\
\text { knowledge }\end{array}$ & $\begin{array}{l}\text { Cultural } \\
\text { sensitivity }\end{array}$ & $\begin{array}{l}\text { Cultural } \\
\text { skill }\end{array}$ & $\begin{array}{l}\text { Diversity } \\
\text { management }\end{array}$ & $\begin{array}{l}\text { Administrative } \\
\text { practices }\end{array}$ & Approaches \\
\hline Mean & 76.42 & 23.14 & 7.96 & 45.32 & 76.90 & 46.49 & 29.79 \\
Median & 78.00 & 24.00 & 8.00 & 47.00 & 80.00 & 48.00 & 32.00 \\
Mode & 80.00 & 24.00 & 8.00 & 48.00 & 80.00 & 48.00 & 32.00 \\
Skewness & -1.32 & -1.26 & -1.27 & -1.12 & -1.14 & -1.230 & -0.94 \\
Kurtosis & 2.25 & 1.99 & 1.42 & 1.50 & .93 & 1.138 & 0.30 \\
\hline
\end{tabular}


When Table 2 is examined, it is seen that the mean, median, and mode values are close to each other, and the skewness and kurtosis coefficients were in the range of +3 and -3 , as Field (2009) suggests. Therefore, it can be said that the distribution did not deviate excessively from normal.

There should be a linear relationship between the predictive variable and the predicted variable (Field, 2009). A scattering diagram has been drawn to examine this. The scatter diagram created for the standardized residual values and the predicted values defines a linear relationship as seen in Figure 2.

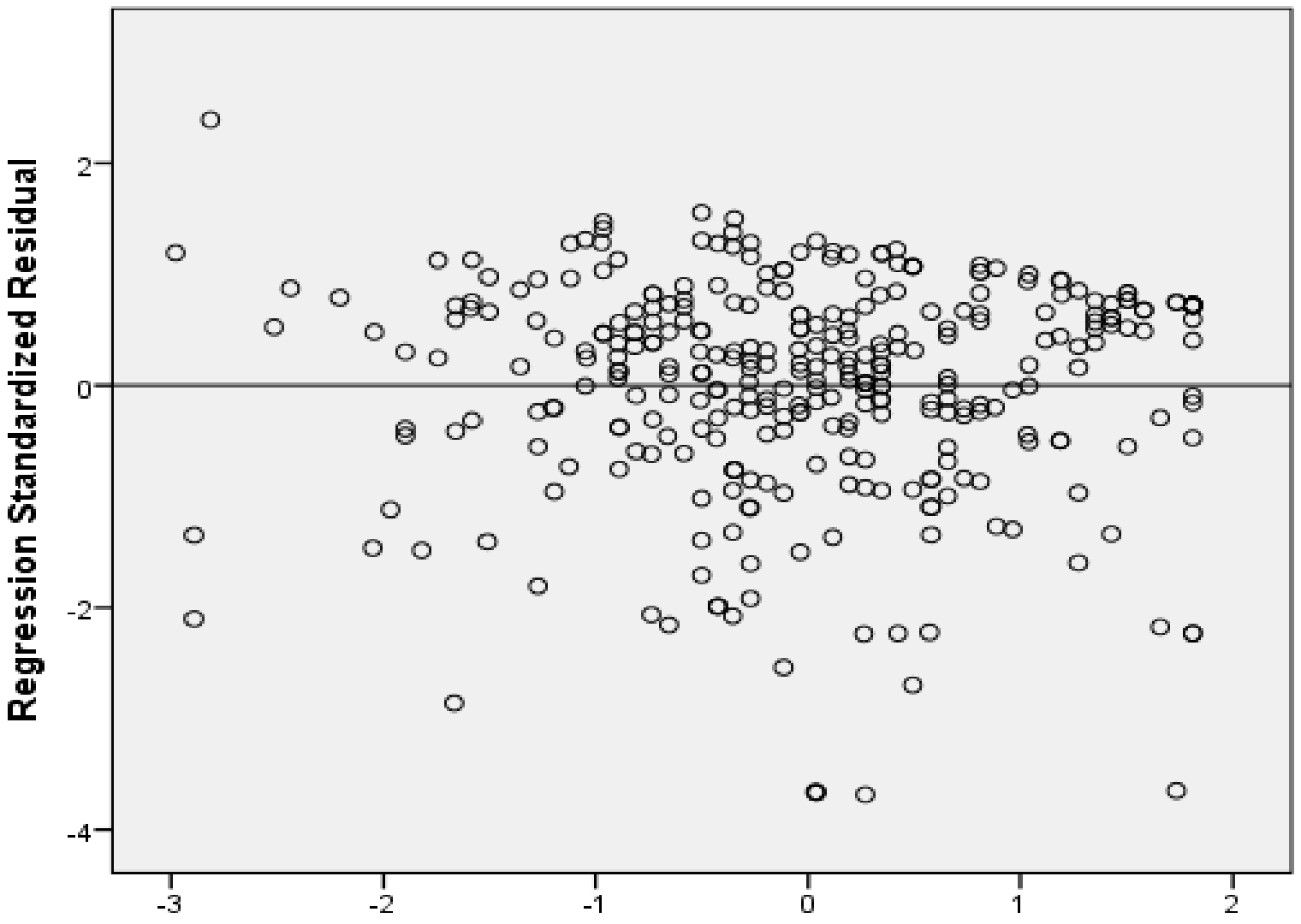

Regression Standardized Predicted Value

Figure 2. Graph Regarding the Existence of Linear Relationship

According to another assumption, variance amplification factor (VIF) values should be less than 10 and tolerance values should be greater than 0.2 (Field, 2009). The variance amplification factors (VIF) and tolerance values were examined, it was seen that the VIF values were less than 10 (between 1.011-1.039) and the tolerance values were greater than 0.2 (between 0.963-0.989). Finally, Mahalanobis distances were calculated to ensure the equation model fit. In the study, the number of independent variables was 1 and Mahalanobis distance point was 6.63 for $p=0.01$ (Can, 2017). 61 extreme values above 6.63 were deleted from the data. With the deletion of these data, the sample decreased to 394. 


\section{Results of Data Analyses}

A hierarchical multiple regression analysis was conducted to determine the predictability of cultural competence to diversity management. Before the regression analysis, the means and standard deviations of the variables and the correlations between these variables were examined. Then, the direct effect between variables was investigated by the hierarchical regression analysis. As a result of the first analysis, correlations of variables with each other, mean and standard deviation scores are presented in Table 3.

Table 3. Mean, Standard Deviation and Correlations of the Variables

\begin{tabular}{|c|c|c|c|c|c|c|c|c|c|c|}
\hline & Variables & $\dot{\mathbf{x}}$ & Sd & 1 & 2 & 3 & 4 & 5 & 6 & 7 \\
\hline 1 & $\begin{array}{l}\text { Cultural } \\
\text { competence }\end{array}$ & 76.42 & 16.89 & 1 & $.916^{\star}$ & $.870^{*}$ & $.977^{\star}$ & $.560^{*}$ & $.573^{\star}$ & $.495^{*}$ \\
\hline 2 & $\begin{array}{l}\text { Cultural } \\
\text { knowledge }\end{array}$ & 23.14 & 5.23 & & 1 & $.782^{*}$ & $.818^{\star}$ & $.538^{*}$ & $.543^{*}$ & $.487^{*}$ \\
\hline 3 & $\begin{array}{l}\text { Cultural } \\
\text { sensitivity }\end{array}$ & 7.96 & 1.95 & & & 1 & $.813^{\star}$ & $.488^{*}$ & $.502^{\star}$ & $.430^{\star}$ \\
\hline 4 & $\begin{array}{l}\text { Cultural } \\
\text { skill }\end{array}$ & 45.32 & 10.64 & & & & 1 & $.535^{*}$ & $.551^{*}$ & $.468^{*}$ \\
\hline 5 & $\begin{array}{l}\text { Diversity } \\
\text { management }\end{array}$ & 76.90 & 19.86 & & & & & 1 & $.976^{\star}$ & $.953^{*}$ \\
\hline 6 & $\begin{array}{l}\text { Administrative } \\
\text { practices }\end{array}$ & 46.49 & 12.01 & & & & & & 1 & $.865^{\star}$ \\
\hline 7 & Approaches & 29.79 & 8.53 & & & & & & & 1 \\
\hline
\end{tabular}

${ }^{*} p<.01$

As seen in Table 3, teacher candidates' general cultural competence levels $\dot{X}=76.42$, cultural knowledge levels $\dot{X}=23.14$, cultural sensitivity levels $\dot{X}=7.96$, diversity management perception levels $\dot{X}=76.90$, administrative practices perception levels are $=46.49$ and approaches perception levels are $\dot{X}=29.79$. There are moderate, positive and significant relationships between teacher candidates' cultural competence, cultural knowledge, cultural sensitivity, cultural skill levels and diversity management perception levels $(r=.560, r=.538, r=.488, r=.535, p<.01)$. There are moderate, positive and significant relationships between cultural competence, cultural knowledge, cultural sensitivity, cultural skill levels and administrative practices perception levels $(r=.573, r$ $=.543, r=.502, r=.551, p<.01)$. There are moderate, positive and significant relationships between cultural competence, cultural knowledge, cultural sensitivity, cultural skill levels and approaches perception levels $(r=.495, r=.487, r=.430, r=.468 p<.01)$. Accordingly, the $\mathrm{H}_{1}, \mathrm{H}_{1 \mathrm{a}}, \mathrm{H}_{1 \mathrm{~b}}, \mathrm{H}_{1 \mathrm{c}}, \mathrm{H}_{1 \mathrm{~d}}, \mathrm{H}_{1 \mathrm{e}}, \mathrm{H}_{1 \mathrm{f}}, \mathrm{H}_{1 \mathrm{~g}}, \mathrm{H}_{1 \mathrm{~h}}, \mathrm{H}_{1 \mathrm{i}}, \mathrm{H}_{1 \mathrm{j}}$ and $\mathrm{H}_{1 \mathrm{k}}$ hypotheses were accepted.

A hierarchical multiple regression analysis was conducted in order to investigate the effect of teacher candidates' cultural competence levels on perception levels of diversity management. In the analysis, gender and grade level, among the demographic variables, were added to the regression equation in the first step as control variables. Analysis findings are shown in Table 4.

Table 4. Hierarchical Multiple Regression Analysis Results Regarding the Prediction of Cultural Competence to Diversity Management 


\begin{tabular}{|c|c|c|c|c|c|c|c|}
\hline \multirow[t]{2}{*}{ Model } & \multicolumn{7}{|c|}{ Dependent Variable (Diversity Management) } \\
\hline & Predictive Variables & B & ShB & $\beta$ & $\mathrm{t}$ & $p$ & $\mathrm{R}^{2}$ \\
\hline \multirow{3}{*}{$\begin{array}{l}\text { 1st Step } \\
\text { (Enter Method) }\end{array}$} & (Constant) & 85.505 & 5.513 & & 15.511 & .000 & \multirow{3}{*}{.011} \\
\hline & Gender & -4.364 & 2.215 & -.101 & -1.970 & .050 & \\
\hline & Grade Level & -1.322 & 1.540 & -.044 & -.858 & .391 & \\
\hline \multirow{4}{*}{$\begin{array}{l}\text { 2nd Step } \\
\text { (Enter Method) }\end{array}$} & (Constant) & 33.139 & 6.055 & & 5.473 & .000 & \multirow{4}{*}{$-.317^{*}$} \\
\hline & Gender & -1.961 & 1.851 & -.045 & -1.059 & .290 & \\
\hline & Grade Level & -1.615 & 1.281 & -.054 & -1.261 & .208 & \\
\hline & Cultural Competence & .655 & .049 & $.557^{*}$ & 13.240 & $.000 *$ & \\
\hline
\end{tabular}

${ }^{*} p<.01$

As seen in Table 4, as a result of the hierarchical multiple regression analysis made after controlling the gender and grade level variables, the cultural competence levels of the teacher candidates significantly predicted their perceptions of the diversity management ( $\beta=.557)$. 31.7\% of the variance in the diversity management is explained by this model $\left(R^{2}\right.$ model $\left.=.317 p<.01\right)$. Almost all of the variance in the model where demographic variables do not make a significant contribution is provided by cultural competence $\left(\mathrm{R}^{2}\right.$ change $\left.=.307 p<.01\right)$. In this direction, the second hypothesis $\left(\mathrm{H}_{2}\right)$ of the study was accepted.

\section{Discussion}

The aim of this paper was to explore, through the lens of the teacher candidates, their cultural competencies for the classes which include students from an ethnically diverse background, at the same time, how these skills of teacher candidates affect to manage this diverse background in their classes. Our research contribution proposes to manage teachers' skills for the practical and theoretical application of cultural competences and diversity in educational settings. Thus, it can be said that there is effect of teacher candidates' cultural competence levels on perception levels of diversity management.

Culture is a tool that shows the process of historical and social development in creating material and moral values and transmitting them to next generations to use, while showing the measure of human domination over the natural and social environment. Since the culture of every society is different, it is not possible to talk about only one culture. Even individuals living in the same society will experience certain cultural differences among themselves, so a certain level of cultural competence is required for an effective communication. While examining the results of this study, it was found that there is a positive and significant relationship between cultural competence and diversity management, so it can be concluded that cultural competences and managing diversity skills of the students in the sample are at a level that can be said to be good. As it can be understood from the findings, one of the reasons why cultural competence was at this level may be that university life offered them an opportunity to live together with individuals from various cultures. This finding supports the idea that higher education should contribute to the social, cultural, economic and political enrichment of the whole society (McArthur, 2011). Moreover, there is a positive and significant relationship between cultural sensitivity and managerial approach, so it should be emphasized here that 
universities provide opportunities for students, but it is important to know to what extent students can make use of these opportunities.

Since universities are educational environments formed by individuals with different abilities, interests, cultures, views, and beliefs, in these environments, students are expected to gain the skills to develop different perspectives on events and people, to be more objective in interacting with individuals from different cultures, and to look at events and facts related to these individuals more flexibly. It is concluded from the findings that there is a positive and significant relationship between cultural knowledge and diversity management.

There is a positive and significant relationship between cultural knowledge and administrative practices. In other words, universities must provide students with opportunuties for comprehending administrative procedures when they have positions in schools. Similarly, according to findings of the study, it can be concluded that cultural competence and diversity management have become more and more important in educational environments because individuals can gain these abilities mostly through school practices before students graduated from university. Therefore, while having multi-cultural communities in countries such as Turkey, ensuring the realization of these competencies is considered as a very important issue. In addition, the finding that there is a positive and significant relationship between cultural skills and management of differences supports this idea. In reviewing the literature published in Turkey, it is evident that increasing the awareness of cultural competence for managing diversity is an issue which should be studied in more detail. Among the existing studies on the subject, Altundağ (2007), Karaeminoğulları, Doğan and Bozkurt (2009), Tuna (2011), and Altay (2005) all emphasized how these parameters are important for providing a multicultural education system with justice.

In this context, it is clear that teacher candidates, to whom future generations will be entrusted, will work with individuals from different cultural backgrounds in their institutions, so they need these competencies. Diversity in their classes comes in the form of not only student race and ethnicity, but also socioeconomic levels, languages spoken, and degree of parental involvement.

Having a positive and meaningful relationship between cultural sensitivity and diversity management is important to create not only respect, but also trust in these different settings. Considering the finding that there is a positive and significant relationship between cultural sensitivity and managerial practices, it can be said for this reason that one way teachers can establish respect with students stems from building an environment centered on cultural competence (Flory \& Wylie, 2019).

Regarding Tuna (2011), contemporary people should know their own culture and at the same time know the characteristics and value of different cultures. According to the findings of the current research, there is a significant positive correlation between cultural competence and approaches. The reason for the increase in this competence is the increase in group activities that teacher candidates participated in, the positive attitudes of the faculty members, the increasing number of friends, and the communication environment established by students with their friends, as stated in the interviews. Guan and Jones (2012) state that university students' adaptability to the region they go to is related to their ability to cope with socio-cultural pressure. Adaptation can also affect their academic performance. Indeed, McKenzie and Schweitzer (2001) state that one of the variables of success at university is compliance with the university.

All in all, it can be concluded that the findings of this research have some similarities and some other perspectives with other studies on the effect of teacher candidates' cultural competencies on their ability to manage differences. 


\section{Conclusion}

This study aimed to determine the effect of cultural competence level on the diversity management perception according to the opinions of teacher candidates. In addition, regarding the adaptation of university students to the environment they go to, Nieto (2008) describes the fact that the cultural competence of university teachers is essential to ensure that international students are welcome and comfortable while studying abroad. Berjawi (2010) emphasizes that increasing our cultural activities will help them increase their cultural knowledge by providing an overview of cultural characteristics and situations.

King (1994) state that cultural knowledge affects behaviors towards individuals representing different cultures, since the finding of cultural competence is an important predictor of diversity management. This supports the idea in the current study that cultural knowledge affects students' attitude towards individuals from different cultures. Managing ethnic diversity in schools to ensure equality for all students is a growing challenge and a really difficult task for school leaders in Turkey, and it is similar in other countries. Although there is a positive and significant relationship between cultural competence and managerial practices, there is evidence that this issue is of international concern because of research that exists in the field of ethnic inclusion in many countries. See, for example, research conducted in a variety of contexts such as Australia (Naidoo, 2009); Belgium (Zanoni \& Mampaey, 2013); England (Blair, 2002) and the Netherlands (Leeman \& Volman, 2001).

Breifly, since teachers perceive their educational needs related to working with different students as exceptional, for teachers to become culturally competent and receive a culturally-sensitive education, teacher education should include courses for dealing with cultural diversity. This is why curriculum improvements of both university-based and alternative teacher preparatory programs are necessary at faculties of education.

\section{Recommendations}

It is important to point out that this area of enquiry is also coming to the fore in a period of great change with the crisis like Covid-19. In our discussion, we have touched on some aspects of the role of student teachers' cultural competences and managing their perceptions of diversity to prepare these students to tackle new kinds of problems to become effectove teachers. There is still a vast potential to create classes with cultural practices which are innovative and representative. The research themes identified in this paper suggest learning approaches and policies and procedures for the implementation of the curriculum by academics and institutions to support prospective teachers to deal with ethnically diverse students in their classrooms. Irrelevant practices may place ethnically diverse students at a distinct disadvantage compared to their non-ethnically diverse counterparts, adding additional barriers while attempting to adjust to new concepts, conventions, curriculums, and ideas.

This research shows that changes are needed to develop pedagogy, establish and implement policies and procedures in education faculties. They should support prospective teachers to deal with cultural differences and diversity in classrooms. Different educational theorists have proposed various solutions. Nieto (2000), for example, advocates the dismantling of existing school structures and the radical reformation of current curricula, policies and procedures, while Gay (2002), on the other hand, proposes an evolutionary approach and puts forward the need for the gradual reconfiguration of classroom pedagogy and preservice teacher training by means of technological innovation. Further investigations, therefore, should study how the representation of multicultural classes and schools are conducive to the communicative styles of most ethnically diverse students who are more active, participatory, and multi-modal (Gay, 2002).

Finally, universities must provide opportunuties for Education Faculty students to improve their cultural competence as it affects the management of diversity. 


\section{Limitations}

As is the case with most qualitative frameworks, there are some limitations which suggest directions for future research (Margolis \& Molinsky, 2008). This research was limited to prospective teachers studying at Artvin Çoruh University, eductaion faculty. Also, it was limited only to the data obtained from the sources available to the researcher on the subject. Since the extent to which the selected sample represents the population cannot be fully confirmed, research findings are unlikely to be generalized to the entire population.

For future research in this field reserachers could develop another dimension that analyzes and explores the role of academics, experience, gender and ethnicity, and an additional layer of participants for developing strategies to manage diversity in the classroom.

\section{Disclosure statement}

No potential conflict of interest was reported by the authors. 


\section{References}

Altay, İ. F. (2005). Developing cultural awareness. Journal of Language and Linguistic Studies, 2(1), 170-182.

Altundağ, P. Y., \& Gökmen, M. E. (2007). Kültürlerarası yeterlilik ve Korece öğretimi [Intercultural competence and Korean teaching] (Unpublished doctoral dissertation). Ankara: Ankara Üniversitesi.

American Speech-Language Hearing Association (2004). Knowledge and skills needed by speech-language pathologists and audiologists to provide culturally and linguistically appropriate services. www.asha.org/docs/.../KS2004-00215.html

Balyer, A. \& Gündüz, Y. (2010). Examining the perceptions of administrators and teachers related to diversity management in their schools. Marmara Üniversitesi Atatürk Eğitim Fakültesi Eğitim Bilimleri Dergisi, 32(32), 25-43.

Berjawi, M. (2010).Cultural literacy awareness kit. MA thesis. Beirut, Lebanon: Lebanese American University.

Blackmore, J. (2010). Preparing leaders to work with emotions in culturally diverse educational communities. Journal of Educational Administration, 48(5), 642-658.

Blair, C. (2002). School readiness: Integrating cognition and emotion in a neurobiological conceptualization of children's functioning at school entry. American Psychologist, 57(2), 111-127.

Burchum, J.L.R. (2002). Cultural competence: An evolutionary perspective. Nursing Forum. doi:10.1111/j.1744-6198.2002.tb01287.x

Can, A. (2017). SPSS ile bilimsel araştırma sürecinde nicel veri analizi [Quantitative data analysis in the scientific research process with SPSS] (5th Ed.). Ankara: Pegem Akademi Yayınevi.

Campinha-Bacote, J. (2002). The process of cultural competence in the delivery of health care services: A model of care. Journal of Transcultural Nursing, 13, 181-184.

Cardno, C., Handjani, M., \& Howse, J. (2018). Leadership practices and challenges in managing diversity to achieve ethnic inclusion in two New Zealand secondary schools. New Zealand Journal of Educational Studies, 53(1), 101-117.

Chrisman, N. J. (2007). Extending cultural competence through systems change: Academic, hospital and community partnerships. The Journal of Transcultural Nursing, 1(18), 68-76.

Clinton, J.F. (1996). Cultural diversity and health care in America: Knowledge fundamental to cultural competence in baccalaureate nursing students. Journal of Cultural Diversity, 3(1), 4-8.

Çakır, Ç. \& Aydın Güngör, T. (2016). Cultural Competence Scale (CCS): The study of adaptation to Turkish, validity and reliability. International Journal of Contemporary Educational Studies (IntJCES), 2(1), 24-36.

Çokluk, Ö., Şekercioğlu, G. \& Büyüköztürk, Ş. (2009). Sosyal bilimler için çok değişkenli istatistik SPSS ve Lisrel uygulamaları [Multivariate statistics SPSS and Lisrel applications for social sciences] (2nd Ed.). Ankara: Pegem Akademi.

Doorenbos, A. Z., \& Schim, S. M. (2004). Cultural competence in hospice. American Journal of Hospice and Palliative Care, 21(1), 28-32.

Doorenbos, A. Z., Schim, S. M., Benkert, R. \& Borse, N. N. (2005). Psychometric evaluation of the Cultural Competence Assessment Instrument among healthcare providers. Nursing Research, 54(5), 324-331

Ergül, H.F. \& Kurtulmuş, M. (2014). Validity and reliablity study of the scale of Diversity Management. Dicle Üniversitesi Ziya Gökalp Eğitim Fakültesi Dergisi, 22(2014), 298-312. 
Eğinli, A. T. (2011). Kültürlerarası yeterliliğin kazanılmasında kültürel farklılık eğitimlerinin önemi [The importance of cultural diversity education in acquisition of intercultural competence]. Öneri Dergisi, 9(35), 215-227.

Field. A. (2009). Discovering statistics using SPSS (3rd Ed.). London: Sage.

Flory, S.B. \& Wylie, R.A. (2019). Cultural competence of urban middle school physical education teachers. Physical Educator, 76(5), $1319-1341$

Gay, G. (2002). Preparing for culturally responsive teaching. Journal of Teacher Education, 53(2), 106-116.

Giffin, R. W. \& Moorhead, G. (2010). Organizational Behavior: Managing People and Organizations. Cengage Lerning. South Western.

Guan, X. \& Jones, G. (2012).Un-Learning and re-learning: The experiences of Chinese undergraduates in a first year management class in New Zealand. Educational Research and Reviews, 7(12), 292-296.

Haas, H. (2010). How can we explain mixed effects of diversity on team performance? A review with emphasis on context. Equality, Diversity and Inclusion, 29(5), 458-490.

Hanley, J. H. (1999). Beyond the tip of ıceberg: Five stages toward cultural competence. Journal of Reaching Today's Youth, 2(3), 9-12.

Hubbard, E.E. (2004). The manager's pocket guide to diversity management. U.S.: Harward Press.

Huskey, M., Deen, M. K. Y. \& Parker, L. (2010). Cultural Competencies for Outreach Professionals. Pullman, WA: Washington State University.

Karaeminoğulları, A., Doğan, A. \& Bozkurt, S. (2009). A research about crosscultural adaptability inventory (CCAl). Süleyman Demirel University, The Journal of Faculty ofEconomics and Administrative Sciences, 14(1), 331-349.

Karasar, N. (2014). Bilimsel araştırma metodu [Scientific research method]. Ankara: Hacettepe: Taş Kitapçılık.

King, J. (1994). The purpose of schooling for African American children: Including cultural knowledge. In E. Hollins, J. King \& W. Hayman (Eds.), Teachingdiverse populations: Formulating a knowledge base (pp. 22 -56). New York: State University of New York Press.

Ladson-Billings, G. (2000). Fighting for our lives: Preparing teachers to teach African American students. Journal of Teacher Education, 51(3), 206-214

Leeman, Y. \& Volman, M. (2001). Inclusive education: Recipe book or quest. On diversity in the classroom and educational research. International Journal of Inclusive Education, 5(4), 367-379.

Leicht-Scholten, C., Weheliye, A. J., \& Wolffram, A. (2009). Institutionalisation of gender and diversity management in engineering education. European Journal of Engineering Education, 34(5), 447-454.

Lenburg, C.B., Lipson, J.G., Demi, A.S., Blaney, D.R., Stern, P.N. \& Schultz, P.R. (1995). Promoting cultural competence in and through nursing education: A critical review and comprehensive plan for action. Washington, DC: American Academy of Nursing.

Lopez, C.M. (2008). School management in multicultural contexts. The International Journal of Leadership in Education, 11(1). 6382. 
Lumby, J. \& Coleman, M. (2007). Introduction: Diversity, leadership and education. Retrieved from http://www.sagepub.com/upmdata/14398_Lumby_Chapter_1.pdf

Magoshi, E., \& Chang, E. (2009). Diversity management and the effects on employees' organizational commitment: Evidence from Japan and Korea. Journal of World Business, 44(1), 31-40.

Maldonado, W.R., Dreachslin, J.L., Dansky, K.H., De Souza, G., \& Gatto, M. (2002). Racial/ethnic diversity management and cultural competency: The case of Pennsylvania hospitals. Journal of Healthcare Management, 47(2), 111-126.

Margolis, J. D \& Molinsky, A. (2008). Navigating the bind of necessary evils: Psychological engagement and the production of interpersonally sensitive behavior. Academy of Management Journal, 51 (5), 847-872.

Mason, J. L.,Benjamin, M. P. \& Lewis, S. A. (1993). The cultural competence model: Implications for child and family mental health services. In C. A. Gilbert \& C. T. Nixon (Eds.), Families and the mental health system for children and adolescents (pp. 165191). U. S., SAGE Publications Inc.

McArthur, J. (2011). Reconsidering the social and economic purposes of higher education. Higher Education Research \& Development, 30(6), 737-749.

McKenzie, K. \& Schweitzer, R. (2001). Who succeeds at university? Factors predicting academic performance in first year Australian university students. Higher Education Research \& Development, 20(1), 21-33.

McPhatter, A. R. (1997). Cultural competence in child welfare: What is it? How do we achieve it? What happens without it? Child Welfare, 76, 255-278.

Naidoo, L. (2015). Educating refugee-background students in Australian schools and universities. Intercultural Education, 26(3), 210-217.

Nieto, C. P. (2008). Cultural competence and its influence on the teaching and learning of International students. Journal of Studies in International Education, 14(4), 406-425.

Nieto, S. (2000). Placing equity front and center: Some thoughts on transforming teacher education for a new century. Journal of teacher education, 51(3), 180-187.

Jabbar, A. \& Mirza, M. (2019). Managing diversity: academic's perspective on culture and teaching. Race Ethnicity and Education, 22(5), 569-588.

Perng, S. J. \& Watson, R. (2012). Construct validation of the nurse Cultural Competence Scale: A hierarchy of abilities. Journal of Clinical Nursing. doi:10.1111/j.1365-2702.2011.03933.x

Rew, L., Becker, H., Cookston, J., Khosropour, S. \& Martinez, S. (2003). Measuring cultural awareness in nursing students. Journal of Nursing Education, 42, 249-257.

Rijamampianina, R. \& Carmichael, T. (2005). General Issues in management. A pragmatic and holistic approach to managing diversity. Problems and Perspectives in Management, 3(1), 109-117.

Shah, S. (2008). Leading multi-ethnic schools: Adjustments in concepts and practices for engaging with diversity. British Journal of Sociology of Education, 29(5), 523-536.

Tanriverdi, G. (2017). Hemşirelikte yeni bir model önerisi: Çevre odaklı kültürel yeterlilik modeli [Suggestion of a new nursing model: Environment focused cultural competency model]. Journal of Human Sciences, 14(4), 4658-4670. 
Thomas Jr, R. R. (1990). From affirmative action to affirming diversity. Harvard Business Review, 68(2), 107-117.

Tuna, S. (2011). Kültürel farkındalık yaratma açısından sanat eleştirisi öğretimi [Teaching art criticism in terms of creating cultural awareness]. Ilköğretim Online, 10(2), 568-575.

U.S. Department of Health and Human Services (2001). Cultural competence works: Using cultural competence to improve the quality of health care for diverse populations and add value to managed care arrangements. $\mathrm{ftp} / / / \mathrm{ftp}$. hrsa.gov/.../cultural_competence.pdf

Weaver, H. N. (1999). Indigenious people and the social work profession: Defining culturally competent services. Journal of Social Work, 44(3), 17-225.

Zanoni, P. \& Mampaey, J. (2013). Achieving ethnic minority students' inclusion: a Flemish school's discursive practices countering the quasi-market pressure to exclude. British Educational Research Journal, 39(1), 1-21. 